\title{
Outbreak of hepatitis C virus infection in hemodialysis unit
}

\author{
Hemodiyaliz ünitesinde hepatit C virüsü enfeksiyonu salgını
}

\author{
(D) Bengü TATAR ${ }^{1}$, DSŞükran KÖSE ${ }^{1}$, (D) Murat SAYAN ${ }^{2,3}$ \\ University of Health Sciences, İzmir Tepecik Education and Research Hospital, 'Department of Infectious Diseases and Clinical \\ Microbiology, izmir, Turkey \\ ${ }^{2}$ Kocaeli University, Medical Faculty, Clinical Laboratory, PCR Unit, İzmit, Kocaeli, Turkey \\ ${ }^{3}$ Near East University, Research Center of Experimental Health Sciences, Nicosia, Northern Cyprus
}

\begin{abstract}
Background and Aims: Hepatitis C virus transmission continues to be a significant public health concern in patients undergoing hemodialysis and occasionally causes outbreaks despite risk reduction after the anti-HCV screening. This study aimed to investigate an outbreak of hepatitis $C$ virus in the hemodialysis unit to identify the infection source and underline lapses in the infection control practices. Materials and Methods: Patients and staff were assessed for hepatitis C virus infection after the outbreak. All anti-HCV-positive patients were tested for genotype or subtypes by performing a phylogenetic analysis of NS3 sequences. The current infection control applications and possible risk factors in the unit were examined to determine the source of infection. Results: Overall, 115 patients, including three patients who were followed up for chronic hepatitis C infection, were evaluated. Anti-HCV seroconversion was detected in 10 new patients. All patients were in the same room and during the same shift. Several lapses in infection control practices were observed. Phylogenetic analysis showed that the outbreak was caused by the same viral strain. Notably, all patients were infected with genotype 1a, and mutations in the NS3 region, subgenotype, and drug resistance were identical to one of the three patients with chronic hepatitis C. Conclusion: Direct observation and molecular test results indicated a transmission from patient to patient, thereby highlighting the importance of infection control.
\end{abstract}

Keywords: Hepatitis C virus, outbreak, hemodialysis

\section{INTRODUCTION}

Hepatitis C virus (HCV) is one of the leading causes of liver disease. Notably, approximately 130-170 million people worldwide have been infected with HCV infection, with a higher prevalence observed in patients undergoing hemodialysis (HD) compared with the general population (1). In our country, approximately $1 \%-8.2 \%$ of patients undergoing HD and $4.8 \%$ of patients undergoing peritoneal dialysis are infected with $\operatorname{HCV}(2,3)$.

HCV transmission continues to be a significant public health concern and may cause outbreaks (4). It is wellknown that HCV does not cross the dialysis membranes;

Correspondence: Bengü TATAR

University of Health Sciences, İzmir Tepecik Education and Research Hospital, Department of Infectious Diseases and Clinical Microbiology, Konak, İzmir, Turkey • Phone: +90 2324696969 • E-mail: b.gtatar@hotmail.com
Giriş ve Amaç: Hepatit C virüs bulaşı hemodiyaliz hastalarında önemli bir halk sağlığı sorunu olmaya devam etmektedir ve hepatit C virüsü taramasından sonra risk azalmasına rağmen zaman zaman salgınlara neden olmaktadır. Bu çalışmada amaç, hemodiyaliz ünitesinde hepatit C virüsü salgınını araştırmak, enfeksiyon kaynağını belirlemek ve enfeksiyon kontrol uygulamalarındaki eksiklikleri vurgulamaktır. Gereç ve Yöntem: Salgın sonrası hastalar ve personel hepatit C virüsü enfeksiyonu açısından tarandı. Tüm anti-hepatit C virüs pozitif hastalar, NS3 sekans filogenetik analizi ile genotip/alt tipler için test edildi. Enfeksiyonun kaynağını belirlemek için mevcut enfeksiyon kontrol uygulamaları ve ünitedeki olası risk faktörleri incelendi. Bulgular: Üçü kronik hepatit C enfeksiyonu nedeniyle takip edilen toplam 115 hasta değerlendirildi. Anti-hepatit C virüs serokonversiyonu 10 yeni hastada tespit edildi; hepsi aynı odada ve aynı seansta diyalize girmekteydi. Enfeksiyon kontrol uygulamalarında birkaç eksiklik gözlendi. Filogenetik analiz, salgının aynı viral suştan kaynaklandığını gösterdi; tüm hastalar genotip 1a ile enfekte ve NS3 bölgesindeki mutasyonlar, subgenotip, ilaç direnci, üç kronik hepatit C hastasından biri ile benzerdi. Sonuç: Doğrudan gözlem ve moleküler test sonuçları hastadan hastaya bulaşmanın varlığını gösterdi ve enfeksiyon kontrolünün önemini vurguladı.

Anahtar kelimeler: Hepatit C virüsü, salgın, hemodiyaliz

thus, the infection is typically transmitted from one patient to the other. Blood transfusion, especially recurrent blood transfusions, is most often the transmission mode (5). Unsafe injections, especially with injectors and needles used several times, are another pathway of HCV transmission (6). Detection of acute hepatitis C (AHC) can be difficult because the infection is typically asymptomatic with normal or only slightly elevated serum aminotransferase levels in patients undergoing HD. Notably, spontaneous HCV clearance occurs in 20\%-30\% of patients after acute infection; however, most often, it progresses to chronic infection $(7,8)$. 
The natural history of chronic hepatitis $\mathrm{C}(\mathrm{CHC})$ infection in patients undergoing HD is ambiguous. Nevertheless, several studies have revealed that it is associated with an increased risk of all complications and liver-related mortality $(9,10)$.

Previously, interferon or pegylated interferon (PEG-IFN) therapy was used in hepatitis $C$ treatment. However, in patients with CKD, low renal clearance caused interferon-related side effects and increased toxicity, and the addition of ribavirin deepened the anemia. Moreover, sustained virologic response (SVR) rates are low (33\%$37 \%)(11,12)$. Nonetheless, the recent development of direct-acting antiviral agents (DAAs) has provided an alternative to interferon-based HCV treatment regimens that are no longer preferred in clinical practice. DAA regimens are shorter, interferon-free, well-tolerated, and highly effective, with SVR rates of 95\%-100\% (13). However, the current therapies for $\mathrm{AHC}$ infection are not available in our country.

This study aimed to identify the source of the outbreak in the clinic and highlight the errors in infection control (IC) measures.

\section{MATERIALS and METHODS}

This study evaluated the outbreak of hepatitis $C$ at one center between February and July 2015. After the outbreak, all patients undergoing HD $(n=115)$ and all personnel $(n=28)$ who worked in this unit were tested for HCV infection. The HCV-RNA test was performed again 15 days and 1 month after the outbreak. During the follow-up period, ALT and anti HCV tests of all uninfected patients were examined for 6 months. Furthermore, the NS3 gene phylogenetic tree analysis of the AHC epidemic was performed to delineate the epidemic nature.

\section{Laboratory analyses}

Cases were tested for anti-HCV (ELISA, Liaison, Diasorin, Italy) and HCV-RNA (Roche, COBAS TaqMan, real-time reverse transcriptase $P C R, v 2.0$; the lower limit of quantification <15 IU/ml). ALT (IU/L), AST (IU/L), total bilirubin $(\mathrm{mg} / \mathrm{dL})$, and direct bilirubin $(\mathrm{mg} / \mathrm{dL})$ were analyzed using the AU5800 auto-analyzer (Beckman Coulter Inc., CA, USA). HCV genotype or subtypes were identified by performing a phylogenetic analysis of the NS3 sequences (codon 27-181 of protease domain). Nucleotide sequences were compared with HCV consensus sequences obtained from strains H77, D90208, HPCPLYPRE, HPCCGAA, HPCJCG, HPCHUMR, HPCCGS, and AY051292. Phylogenetic comparisons were performed using the neighbor-joining method (CLC Sequence Viewer 6.9.1 Bio A/S, Denmark).

\section{RESULTS}

The clinic had 115 patients undergoing HD, of which three were chronically infected with $\mathrm{HCV}$, and a separate machine was used for them.

One patient who was negative on the routine screening tests in January 2015, seroconverted to anti-HCV antibody positivity in February 2015. Subsequently, the staff and patients were tested for HCV infection. The staff were noted to be negative. In the follow-up period, anti-HCV seroconversion occurred in 10 more patients (7 males, 3 females) who were seronegative before; seven were detected in two months. Subsequently, three additional cases were reported. The characteristics of patients are presented in Table 1.

All the newly infected patients had received HD in the same room on the same shift, along with one of the

Table 1. Characteristics of patients

\begin{tabular}{|c|c|c|c|c|c|c|c|}
\hline Patient & 1 & 2 & 3 & 4 & 5 & 6 & 7 \\
\hline Sex & $\mathrm{F}$ & M & $\mathrm{F}$ & M & M & M & M \\
\hline Age (year) & 56 & 42 & 34 & 77 & 50 & 71 & 34 \\
\hline Hemodialysis Time (year) & 4 & 8 & 2 & 1 & 17 & 4 & 4 \\
\hline Anti-HCV & + & + & + & + & - & + & + \\
\hline \multicolumn{8}{|l|}{ HCV-RNA } \\
\hline (IU/ml) & $8.7 E+6$ & $1.08 \mathrm{E}+6$ & $5.1 \mathrm{E}+7$ & $1.5 E+1$ & $1.6 \mathrm{E}+6$ & $6.7 E+4$ & $3.7 E+5$ \\
\hline $\operatorname{ALT}(\mathrm{U} / \mathrm{L})$ & 318 & 358 & 334 & 28 & 95 & 74 & 105 \\
\hline Total bilirubin (mg/dL) & 12.3 & 4.6 & 2.0 & 0.3 & 2.8 & 0.7 & 0.7 \\
\hline Ishak score & 1 & 3 & - & - & 4 & - & - \\
\hline
\end{tabular}

ALT: Alanine transferase. HCV RNA: Hepatitis C virus ribonucleic acid. 
Table 2. Sequence information of cases

\begin{tabular}{ll}
\hline Genetic region & NS3 \\
\hline Predicted subgenotype & 1a (similarity of DNA to the closest reference $=95.64 \%)$ \\
\hline Predicted clade of subgenotype & I (similarity of DNA to the closest reference $=95.64 \%)$ \\
\hline Codons covered in NS3 region & $52-181$ (relevant positions not covered: 36,43$)$ \\
\hline Mutations in NS3 region & L153I, N174S \\
\hline Reference used & H77
\end{tabular}

NS: Nucleotide sequences

Table 3. Drug resistance of cases.

\begin{tabular}{|lll}
\hline Drugs & Scored Mutations & Resistance Analysis \\
\hline Boceprevir & $174 S$ & Substitution on scored position \\
\hline Paritaprevir & None & Susceptible \\
\hline Simeprevir & None & Susceptible \\
\hline Telaprevir & $174 S$ & Possibly resistant \\
\hline
\end{tabular}

patients with $\mathrm{CHC}$. Three patients were followed up at another center; hence, their sequence information and drug resistance could not be examined. All patients were infected with genotype $1 \mathrm{a}$ and had the sequence information and drug resistance similar to the patient with $\mathrm{CHC}$ (Tables 2 and 3). This case was defined as the index case. Mutations in the NS3 region, subgenotype, and drug resistance were identical to the index case.

During the follow-up period, one patient died within two months of diagnosis, and two patients did not develop $\mathrm{CHC}$ infection. Three cases had pruritis, five cases had fatigue, and three cases were asymptomatic. During the eighth week, seven patients with HCV-RNA positivity were scheduled to receive PEG-IFN therapy; however, the treatment could not be commenced because of low hemoglobin levels and refusal of the treatment.

\section{DISCUSSION}

$\mathrm{HCV}$ infection is more common among patients on dialysis than in the general population. Despite reduced incidence, intermittent outbreaks continue to occur in the dialysis units (14). The American Association for the Study of Liver Disease and Center for Disease Control and Prevention recommends HCV screening for specific groups based on demographics, possible exposures, high-risk behaviors, and medical conditions, such as people who receive blood and blood products, IV drug users, patients on dialysis, people with persistently abnormal liver enzymes, children born to HCV infected women, and healthcare workers exposed to needlesticks, sharps, or mucosal exposures to HCV infected blood $(15,16)$. Even though no HCV transmission occurs via the dialysis machine, blood transfusions, dialysis duration, dialysis type, and the prevalence of $\mathrm{HCV}$ infection are risk factors for HCV infection among patients undergoing dialysis. Additionally, anti-HCV false-negativity can be observed more frequently in immunocompromised patients than immunocompetent patients and can cause virus transmission $(15,17)$. Anti-HCV negativity may be present in the hyper-acute phase, such that anti-HCV positivity could not be detected in one of the patients during the outbreak. The diagnosis of $\mathrm{AHC}$ in this patient was determined through serum HCV-RNA positivity. Moreover, acute infections are typically asymptomatic and anicteric, thereby causing increased transmission risk. Outbreaks of new $\mathrm{HCV}$ infections are associated with lapses in IC, including improper parenteral medication handling and preparation, inadequate cleaning and disinfection of environmental surfaces between patient treatments, and poor hand hygiene and glove use $(18,19)$. We evaluated the patient intake and IC practices in this clinic. We identified lapses in IC, such as hand hygiene and glove use, vascular access care, parenteral medication preparation and administration, environmental and machine surface cleaning and disinfection between shifts and at the end of the day. We observed the lack of hand hygiene and glove changes during vascular interventions and inter-patient transitions. The same sequence information and drug resistance identical to one of the patients with chronic 
HCV infection who was in the same HD room and on the same shift as all new cases suggested that the outbreak was associated with transmission between patients, thereby revealing the lapses of IC in this clinic.

Detection of the same viral strain in this outbreak thereby emphasizes the importance of adhering to the recommended IC practices in dialysis settings, as well as highlights the importance of routine hepatitis C screening in patients at increased risk of infection.

\section{REFERENCES}

1. Lavanchy D. Evolving epidemiology of hepatitis C virus. Clin Microbiol Infect 2011;17:107-15.

2. Gower E, Estes C, Blach S, Razavi-Shearer K, Razavi H. Global epidemiology and genotype distribution of the hepatitis $C$ virus infection. J Hepatol 2014;61(1Suppl):45-57.

3. Altuglu I, Soyler I, Ozacar T, Erensoy S. Distribution of hepatitis $C$ virus genotypes in patients with chronic hepatitis $C$ infection in Western Turkey. Int J Infect Dis 2008;12:239-44.

4. Perz JF, Grytdal S, Beck S, et al. Case-control study of hepatitis B and hepatitis $C$ in older adults: Do healthcare exposures contribute to burden of new infections? Hepatology 2013;57:917-24.

5. O'Brien SF, Yi QL, Fan W, et alç Current incidence and residual risk of HIV, HBV and HCV at Canadian Blood Service. Vox Sang 2012;103:83-6.

6. Kermode M. Unsafe injections in low-income country health settings: need for injection safety promotion to prevent the spread of blood-borne viruses. Health Promot Int 2004;19:95-103.

7. Loomba R, Rivera MM, McBurney R, et al. The natural history of acute hepatitis $C$ : clinical presentation, laboratory findings and treatment outcomes. Aliment Pharmacol Ther 2011;33:559-65.

8. Maasoumy B, Wedemeyer $\mathrm{H}$. Natural history of acute and chronic hepatitis C. Best Pract Res Clin Gastroenterol 2012;26:401-12.

9. Liu $\mathrm{CH}, \mathrm{KaO} \mathrm{JH}$. Treatment of hepatitis $\mathrm{C}$ virus infection in patients with end-stage renal disease. J Gastroenterol Hepatol 2011;26:22839.

10. Fabrizi F, Takkouche B, Lunghi G, et al. The impact of hepatitis $C$ virus infection on survival in dialysis patients: meta-analysis of observational studies. J Viral Hepat 2007;14:697-703.
Ethics approval and consent to participate: Not applicable. This article does not contain any studies conducted by any of the authors on humans or animals.

Conflict of interests: The authors declare that they have no conflict of interests.

Acknowledgments: The authors would like to thank everyone in the hemodialysis clinic

Funding: The authors received no specific funding.

11. Russo MW, Goldsweig CD, Jacobson IM, Brown RS Jr. Interferon monotherapy for dialysis patients with chronic hepatitis $C$ : an analysis of the literature on efficacy and safety. Am J Gastroenterol. 2003;98:1610-5.

12. Bunchorntavakul C, Maneerattanaporn M, Chavalitdhamrong D. Management of patients with hepatitis $C$ infection and renal disease. World J Hepatol 2015;7:213-25.

13. Pawlotsky JM. New hepatitis $C$ therapies: the toolbox, strategies, and challenges. Gastroenterology 2014;146:1176-92.

14. Fabrizi F, Messa P. Transmission of hepatitis $C$ virus in dialysis units: a systematic review of reports on outbreaks. Int J Artif Organs 2015;38:471-80.

15. Ghany MG, Strader DB, Thomas DL, Seeff LB. Diagnosis, management, and treatment of hepatitis $C$ : an update. Hepatology 2009;494:1335-74.

16. Centers for Disease Control and Prevention (CDC). Recommendations for prevention and control of hepatitis $C$ virus (HCV) infection and HCV-related chronic disease. MMWR Morb Mortal Wkly Rep 1998;47(RR-19):1-39.

17. Centers for Disease Control and Prevention (CDC). Testing for HCV infection: an update of guidance for clinicians and laboratorians. MMWR Morb Mortal Wkly Rep 2013;62:362-5.

18. Patel PR, Thompson ND, Kallen AJ, Arduino MJ. Epidemiology, surveillance, and prevention of hepatitis $C$ virus infections in hemodialysis patients. Am J Kidney Dis 2010;56:371-8.

19. Thompson ND, Novak RT, Datta D, et al. Hepatitis C virus transmission in hemodialysis units: Importance of infection control practices and aseptic technique infect control hosp. Infect Control Hosp Epidemiol 2009;30:900-3. 